\title{
Backing your brand
}

\author{
Sue Charles \& Chris Fisher \\ Branding is one of the most important and powerful aspects of building a business, but it requires delicate \\ maintenance to keep it working for you instead of against you.
}

Tol ruly successful businesses-biotech or otherwise-not only need a great product offering but also must establish their position as leading brands that are immediately recognizable in their sector. 'Branding' can be confusing, however, with companies and customers having their own concept of what a 'brand' really is.

In the biotech sector, companies often neglect brand identity because, unlike other industries, they lack tangible products. As most energy is expended on product development-and convincing investors to give their money to finance further product development-it's easy to let branding drop down the list of priorities.

But branding is not just limited to products; it can be essential for effectively communicating the value of your company's equity to stakeholders. This is especially critical in an industry in which perceptions and confidence are major drivers of value. And it remains true whether the economy is expanding or contracting (Box 1).

\section{Your first move}

So, how do you create a brand identity? You should start by coming up with the right name and logo. Do you really want to call your company Birmingham Proteins if you're planning to broaden your horizons to antibodies and RNAi in five years' time? Similarly, you should be wary of cultural mores. Names in one language might not translate well in others; thus, naming your new startup in Naples Gen Italia might not be optimal if you are seeking to raise serious money from English-speaking investors.

Sue Charles is managing partner and Chris Fisher is associate partner, creative director at College Hill Life Sciences, London, UK. e-mail: sue.charles@collegehill.com or chris.fisher@collegehill.com

\section{Box 1 Branding in a recession}

Does the economic downturn have an effect on how much businesses spend on their brand? It can, but customer loyalty is critical during a recession; you still need to communicate with all your stakeholders during difficult times. In this climate, it is important for companies to balance their communications budgets-to spend nothing sends the wrong messages, yet to overspend can be more damaging. Take annual reports, for example, which are a key branding tool; we are now seeing a trend of companies moving away from very expensive and glossy publications to something simpler and more understated. This can be a highly effective approach if used in a smart way.

It is vital to ensure that your brand is in the best position when the economic climate changes for the better. At the same time, downturns can offer many possibilities to reposition a company so it gains major competitive advantages when the market swings back. For example, Biota (Melbourne, Australia), a biotech that develops anti-infectives, has been able to make a good recovery because of the H1N1 flu pandemic. The company has emerged from the industry downturn and has positioned itself nicely for its next strategic phase. Within our own company, College Hill Life Sciences (London), we chose to invest in expansion into the United States to internationalize our offering in 2009, at the height of the downturn. Now that we are coming out of the gloom, this positioning is paying dividends.

Choose a name and logo wisely and make it link to what you do. If you have a strong brand identity, people should be able to instantly recognize what your business does, what it offers and what they can expect. For example, Genentech (South San Francisco, California) is a global brand with a strong personality built up through delivering on its promises. In addition, Genentech has one of the most memorable and sought-after website addresses in the industry-http://www. gene.com. If people do not know your company name, cannot relate to it or if it means different things to different people, then you have failed in creating your brand identity.

Choosing a logo is influenced by many factors, including your competitor's logos and your general business environment; the technical practicalities; the complexity of the overall visual identity and the role the logo plays; the personality of the company; and how the logo will be influenced by long-term business objectives.
But this is just the beginning. Successful branding is not achieved by just a logo or name. You must capture a company's or product's purpose and successfully communicate it to stakeholders through images, words and dialog. It's your promise to your audience-you must tell them what they can expect from your company and what differentiates you from your competitors.

\section{Brand elements}

You can only build a brand once you have a clear picture of what your business is. What are your goals and aspirations? How do you want audiences to perceive your company? A startup biotech should always begin by developing its identity and looking at its positioning. Do your market research—what are you offering, where do you sit in the market and where do you want to go? To answer these questions, a brand agency will use appropriate processes, workshops and market research to establish the key information and messages 


\section{Box 2 Essential elements}

Although many scientific entrepreneurs might shudder at the 'touchy-feely' world of marketing, it is a vital part of any business - whether the company deals in lollipops or locked nucleic acids. Below are the essential elements to consider when trying to build a successful brand.

Vision, mission and values. These will make clear your long-term strategic goals, your tactics to achieve these goals and what you stand for and believe in.

Personality and behavior. Are you serious, corporate and financially led? Or are you more visionary, approachable and diverse?

Brand proposition. What is your brand promising to your audiences, and what will they experience?

Name and logo. Any company needs a recognizable written name and graphical logo (preferably not a hackneyed DNA helix!).

Visual identity and framework. This visual platform will serve as both the underlying structure and the styled content of your communications.

Key messages. These make clear who you are, what you do, what you offer and what people can expect from you.

Benefits and labeling (of technology, products and services). You should use persuasive and clear terminology that is understood by your audiences and that conveys the purpose and benefits of your product.

Market positioning. Be sure to create ownership of a defined market for your company that allows it to prosper alongside competitors. There is an audience that will choose you.

Target audience. Identify the type of people you want to engage with, who will also benefit from knowing about you.

Brand consistency. From corporate stationery and presentations to e-mail signatures and phone greetings, everything about your brand should be consistent and managed.

Brand guidelines. How should the brand be managed, what design templates should staff be using, where and when should a logo be used and what is the company's style and tone? All these questions must be outlined in an easy-to-use reference manual.

Follow-through. You must deliver on your promises. All audiences will have a memory of you through their experiences; make sure it is a great one.

that will feed into building your brand.

Successful companies have a clear positioning and identity, know where they want to be in the future and know how to develop and use their brand to meet business objectives. Don't ever try to be everything to everyoneyou won't be. And be true to both your vision and reality (Box 2).

Anecdotal evidence suggests that a CEO's reputation accounts for up to $40 \%$ of a company's reputation. For successful branding, it is crucial that CEOs lead by example and capture the essence of the brand through their words and actions - the person at the top should always be seen as the embodiment of their company's brand. Genentech CEO Arthur Levinson is a notable example: he made the scientist-as-chief-executive persona work for him and the company, which was always seen as innovative and slightly away from the pharma mold-a positioning that might not have been possible with an expharma man at the top. (In April, following Genentech's $\$ 47$ billion merger with Roche (Basel, Switzerland), Levinson left day-to-day operations after decades at the helm, though he still leads the board of directors.)

The CEO of a company needs to understand what the brand is, all the influences on it and what it means to different stakeholders. Additionally, the CEO's behavior can have a dramatic effect on how the brand is perceived. Indeed, from the top down it's vital for all company employees to believe in and understand the brand.

\section{Brand strategy}

A strong and successful brand drives a business forward, represents the goals of the stakeholders and creates loyalty and confidence. This is accomplished through an effective brand strategy (Box 3 ).
The key is to have clear and consistent communications that deliver what you promise. For example, which business is more likely to have a brand that resonates with its audience: one that is poorly organized with bad communications and technology no one understands or one that always delivers and has clear and effective communications? In biotech we are predominantly selling the 'hopes and dreams' of tomorrow, and the better you can convey that, the more successful your brand will be.

Your brand must always be a true reflection of your company-you cannot call yourself a global company if your business consists of just two people working in a small office 100 miles north of London. Unless your goal is to rapidly grow your business across the world, there will be a disconnect between the brand and the audience's experience of it, and the brand will become irrelevant. You should find your place in the market and ensure your branding reflects both your current status and your near-term vision.

Successful companies quickly embrace the importance and value of brand communications. They don't have to be the loudest-it's not about volume; it's about projecting the right image with measured communications to help attract investors, customers and employees. It is critical for all employees to be on board, from the CEO to the frontline staff. Everyone in your company needs to play a part in creating an effective brand.

If you have the resources, working with the right brand communications agency can also help because the agency has experts with the right skills and know-how to create, build and drive your brand. If you're a smaller biotech that has no in-house communication, branding or design experts, it's important that you find an outside agency that has the experience to develop the branding strategy. In larger companies, external expertise can also provide a more balanced view of reality than in-house teams, which may be too wrapped up in corporate messages and details to fully understand what will resonate with external audiences.

Whatever the choice of agency, you need to be sure you like their work and how they do it before hiring. The right one will understand the challenges of your market, the concerns of your leadership team and the expectations of your audiences. The agency should be able to develop a brand that will create interest in your company and build emotional connections with your customers.

An agency should also question your views and decisions; for example, some leadership teams believe that they regularly need to 
refresh their brand as they hit certain targets and milestones. But if you're delivering what you're promising, then there probably is no need to change your brand. Your agency should be working with you to look at how your brand will be affected before you hit your milestones. As you mature, you need to update your brand and messages-but these changes should, in general, be evolutionary. The only time you should be looking to review your brand is after a business-changing situation, such as a merger or acquisition, or if your company is going to move in a new direction.

A recent report on the cancer sector highlighted that Genentech was the leading company as measured by sales, products, $R \& D$ and corporate equity. Roche was ranked 15 th. Genentech was also the number-one company when ranked by overall image performance ${ }^{1}$. It will be interesting to follow these metrics in the aftermath of the Roche takeover of Genentech.

On the merger and acquisition theme, the industry will be watching with interest how the Invitrogen (Carlsbad, California) and Applied Biosystems (Foster City, California) brands will fare under the new umbrella name of Life Technologies (Carlsbad) following their merger at the end of last year. The branding strategy appears set up to allow well-known brands to be acquired but retain their individual brand identity with the added endorsement from Life Technologies.

\section{Media channels}

Never have brands and communications been more under the spotlight than with the explosion of online blogging, social networking sites and 24/7 news feeds. It's important that you and your company maximize the potential of the Internet to promote the brand and connect with audiences across the world.

There are many social networking sites that can be used to create exposure for a brand and gain some excellent and cost-effective coverage, but you must always understand how these sites can be used to both your advantage and your disadvantage and why they are useful before you jump in. Again, the right agency will be able to provide the best advice for your individual needs. A good way to see how social networking sites are being used in the industry is to monitor how your competitors and the industry leaders are using these communications channels, especially what is being communicated and how frequently. Social media sites can be equally destructive to a brand, and any online strategies must be carefully managed. Two good questions to ask

\section{Box 3 Planning your voice}

Determining and conveying your company's brand takes a great deal of managing and forethought. Here are some questions to keep in mind.

What messages is your company communicating? Are you the market leader and the most responsible? Are you the most advanced? Do you have the biggest potential or the best-inclass products?

How will you disseminate these messages? Will you use traditional print and online media or webinars and podcasts? Will you embrace the new tools of social networking and reach out to new audiences?

When will you communicate your messages? What are the best times for maximum impact and coverage? When and what are your competitors communicating? Are there any legal requirements that affect timing? Will different time zones affect the impact of your communications?

Where will you communicate these messages? What do your audiences read and how do they get their information? How can you maximize coverage and exposure, and which events and conferences are worth attending?

Who are your target audiences and how will your brand engage with them? Audiences might be customers, investors, partners, suppliers, current and future employees, media and the local community-how will you tailor your messages so they have significance to all your audiences?

are: will the site add credibility and valuable interest to my business, and will the investment in time bring a valuable return? These tools should be considered when planning any communications strategy.

Maximizing the potential of the Internet begins with your own website, which is the first contact most people will have with your company. It is vital to make the right first impression and attract repeat visitors-your company website is your shop front.

Our experience has shown that companies aren't always focused on their websites. There have been many occasions when a company has revised its business strategy and yet the brand and website have remained the same. The outside world will always see your website as a reflection of your company-make it relevant and professional. Ensure that it's up to date and that messages are congruent with all other channels of communication. It doesn't have to cost a fortune. An effective way of evaluating the relevance and standard of your website is to involve key stakeholders who represent all areas of your business, making sure everyone has a voice. This can also be an excellent way of promoting initiative and strengthening relationships both throughout the company and with suppliers and key contacts. The challenge is facilitating and monitoring the input; this is where an agency can provide a valuable and independent link to manage and extract the contribution of stakeholders and ultimately provide the advice needed to evolve the website.

\section{Don't hurt yourself}

For all the striving to establish a brand, a few wrong moves can wreck all that hard work. There are several factors that can have a negative effect on your brand.

Inaccuracy. If you do not deliver on your promises, customers and stakeholders will not have any trust in your business. A good example is advertising: it is too easy to project a certain image, set an expectation, invite customers to call your company and then not properly brief and train the employee who is answering the phone-or worse, leave a caller trapped in an automatic answering system. A consumer's experience of your brand can damage or improve how your brand is perceived.

Poor communication. You need to invest in encouraging regular feedback from audiences. Ensure they fully understand your business and allow them the opportunity to provide constructive feedback on your products and/or services. An effective mechanism could be on a website, where you would be inviting feedback with a clear incentive and benefit.

Complacency. It is very easy to sit back on your reputation when everything is going well and you are an industry leader, but that's the time when your brand is at most risk from adverse publicity. Make sure you stick to your brand strategy and that you have planned for 
potential issues. Just as importantly, remain competitive and push the brand further. GlaxoSmithKline (Brentford, UK) has made some recent changes that are a good example. The appointment of Andrew Witty as CEO has been accompanied by a visible change in the communications output, as the company both defends and pushes its brand as an open and trusted leader in the pharmaceutical sector despite accusations that the industry is profiteering from the threat of pandemic flu.

Inconsistency. Make sure your brand communication strategy is consistent so stakeholders will get the right information at the right time in the right format. To ensure this is achieved every time, it is critical to establish clear procedures so that every element meets the company's standards and expectations.

\section{Parting thoughts}

A brand helps present your company to the rest of the world. You can create a successful brand only through a long-term relationship with your stakeholders, whether they are customers, employees, partners, investors or suppliers. Your business must assess how the brand delivers on both internal and external expectations. Ultimately, creating a successful brand will help drive value. Successful branding can essentially be accomplished in six ways: understand who you are (and who you are not); ensure your investment in branding adds value; communicate messages clearly; have an engaging visual identity; make sure your brand proposition is what your audiences actually experience; and take advantage of the speed and globalization of communication to spread the word.

1. Carlin, P. \& Gordon, E. Why cancer KOLs love Genentech. Scrip World Pharmaceutical News 3446 , 22 May 2009, pp.28-30.
To discuss the contents of this article, join the Bioentrepreneur forum on Nature Network: http://network.nature.com/groups/bioentrepreneur/forum/topics 